\title{
Composition of Hawaiian green turtle foraging aggregations: mtDNA evidence for a distinct regional population
}

\author{
Peter H. Dutton ${ }^{1, *}$, George H. Balazs ${ }^{2}$, Robin A. LeRoux ${ }^{1}$, Shawn K. K. Murakawa ${ }^{2}$, \\ Patricia Zarate ${ }^{3}$, Laura Sarti Martínez ${ }^{4}$ \\ ${ }^{1}$ NOAA Fisheries, Southwest Fisheries Science Center, 8604 La Jolla Shores Drive, La Jolla, California 92037, USA \\ ${ }^{2}$ NOAA Fisheries, Pacific Islands Fisheries Science Center, 2570 Dole Street, Honolulu, Hawaii 96822-2396, USA \\ ${ }^{3}$ Charles Darwin Foundation, Santa Cruz, Galapagos Islands, Ecuador \\ ${ }^{4}$ CONANP, Camino al Ajusco No. 200, Col. Jardines en la Montaña, Tlalpan, México DF CP 14210, Mexico
}

\begin{abstract}
To examine the stock composition of Hawaiian foraging populations and evaluate current life-history hypotheses, mtDNA control region sequences from immature and adult green turtles that forage around the Hawaiian Islands were compared to potential source nesting populations across the Pacific. We examined the stock composition of the feeding ground (FG) populations at 5 index sites across the Hawaiian Archipelago, as well as animals stranded in areas outside these index sites. Six haplotypes, based on mtDNA sequences, were observed among the 788 green turtles sampled around the Hawaiian Islands. Stock mixture analysis shows that the Hawaiian FG populations comprise one genetic stock derived from the nesting population at French Frigate Shoals (FFS), based on a mean estimate of $99.9 \%$ from FFS as opposed to other potential source stocks. We identified only 3 turtles with haplotypes not found at FFS, indicating that Hawaiian FGs might occasionally, albeit rarely, be visited by animals from rookeries outside the Hawaiian Archipelago, both in the eastern and western Pacific. These findings lead us to conclude that the numerous foraging aggregations around the Hawaiian Islands can be considered part of a distinct regional population for management. The finding that FGs scattered across a distance of over $2400 \mathrm{~km}$ belong to one genetic stock is unique among sea turtles, and allows Hawaiian green turtles to be assessed separately from other Pacific stocks with respect to risk. We explore the unique population ecology of Hawaiian green turtles with reference to the complex life history of this marine megaherbivore.
\end{abstract}

KEY WORDS: Population genetics · Control region · Mitochondrial DNA · mtDNA · Sea turtles Resale or republication not permitted without written consent of the publisher

\section{INTRODUCTION}

The green turtle Chelonia mydas occurs throughout the many coral reef and coastal foraging grounds (FG) within the Hawaiian Archipelago, which consists of more than 130 islands and reefs spanning approximately $2400 \mathrm{~km}$ (see Fig. 1). The only significant nesting assemblage occurs at French Frigate Shoals (FFS), a mainly uninhabited reef with several sand islets located in the middle of the archipelago (see Fig. 1), although it appears that some nesting occurred at the southeastern end of the archipelago prior to European settlement (Balazs 1985a), and low-level nesting occurs elsewhere in the northwestern Hawaiian Islands. The FFS nesting population of threatened green turtles has been monitored since 1973 and is one of the few populations in the Pacific that appears to be increasing in numbers (Balazs \& Chaloupka 2004a, 2006, Hays 2004, Chaloupka \& Balazs 2007), along with Ogasawara (Japan), and Heron Island (Australia) (Chaloupka et al. 2008). Although the Hawaiian nesting population is genetically distinct from other Pacific stocks (Dutton et al. unpubl. data), there is no genetic information on stock composition among FGs within the Hawaiian Archipelago. This reflects a more general limitation in the way sea turtle populations are defined, assessed, and managed. Popu- 
lations are often considered to be either a rookery or a group of rookeries of various geographic scales (Dutton et al. 1999, Reece et al. 2005), since it is more challenging to delineate stock boundaries that include foraging, migratory and developmental regions in the marine environment (Chaloupka 2004, Chaloupka et al. 2004, Bowen et al. 2005). This is because sea turtles, like other highly migratory marine vertebrates, have complex life histories. Adults breed at rookeries and migrate to FGs that usually draw animals from multiple genetic stocks spanning a large area (see Bowen 1997). Usually, adults and juveniles from one rookery also disperse to several different FGs. Furthermore, juvenile sea turtles usually have an early pelagic phase that may encompass large areas of open ocean.

In the Hawaiian Archipelago, immature green turtles generally recruit to the southern FGs once they reach sizes of approximately 35 to $40 \mathrm{~cm}$ straight carapace length (SCL) after pelagic development in the northern Pacific Ocean (Balazs 1982, Zug et al. 2002, Balazs \& Chaloupka 2004a,b), although juveniles as small as $30 \mathrm{~cm}$ SCL may occasionally be found around the northwestern portion of the archipelago (Balazs 1976). Based on growth rates, the duration of this oceanic developmental phase is estimated at $6 \mathrm{yr}$ or more for Hawaiian green turtles (Zug et al. 2002). It is thought that the Hawaiian foraging populations are derived primarily from the FFS rookery (Balazs et al. 1987); however, it has been difficult to evaluate this hypothesis based on tagging data alone, since it has not been possible to track hatchlings from the nesting beaches to adult FGs using traditional tagging methods.

Studies of maternally inherited mtDNA in green turtles have been useful in understanding the population structure and reproductive behavior of these highly migratory marine animals (Bowen et al. 1992, FitzSimmons et al. 1997) and in demonstrating the existence of distinguishable stocks for management (Moritz 1994, Bowen \& Karl 1997). The presence of fixed or nearly fixed differences in haplotype frequencies between nesting populations is now sufficiently characterized in green turtles (Lahanas et al. 1994, Norman et al. 1994, Encalada et al. 1996, Dethmers et al. 2006, Bourjea et al. 2007) that mtDNA alleles can be used as genetic markers to determine the natal origins of juvenile turtles sampled in their developmental habitats or along migratory pathways (Bass et al. 1998, 2006, Lahanas et al. 1998, Bass \& Witzell 2000, Luke et al. 2004). All studies to date indicate that FG aggregations are made up of stocks of mixed origins, with relative stock mixes differing significantly from location to location. Recent mtDNA surveys of Pacific green turtle nesting populations show that the FFS rookery is distinct from others in the eastern and western Pacific (Bowen et al. 1992, Chassin-Noria et al. 2004, Dethmers et al. 2006, P. H. Dutton et al. unpubl. data, and these studies provide a baseline to evaluate stock composition of the Hawaii FGs.

The present study investigates the genetic stock composition of foraging green turtle aggregations in the Hawaiian Archipelago to infer dispersal patterns of green turtles in the central Pacific, and to determine whether these foraging aggregations are part of the same breeding population. We use this genetic approach of mtDNA sequence analysis, combined with information on life history and demographics, to expand knowledge of the ecology of green turtles in this region. Our findings are relevant to the status and current conservation issues relating to recognition of the Hawaiian green turtle population as a distinct demographic entity or management unit (MU, see Moritz 1994, Fraser \& Bernatchez 2001), and correct classification of this population segment under the US Endangered Species Act (ESA).

\section{MATERIALS AND METHODS}

Field sampling. MtDNA control region sequences were obtained from blood or skin samples collected during 1995 to 2003 from juvenile, sub-adult and adult green turtles captured in 5 Hawaiian Archipelago FGs as part of a long-term Capture-Mark-Recapture (CMR) program (Balazs 1976, 1982, 2000, Balazs et al. 1994, 2005, Balazs \& Chaloupka 2004b). Blood samples were collected using protocols designed not to harm the turtles, as described in Dutton (1996). The FG samples were obtained from Midway Atoll, Kane'ohe Bay (O'ahu), Pala'au (Moloka'i), and from the east and west sides of the island of Hawai'i at Kiholo Bay and Punalu'u Bay (Fig. 1). Details of the study sites and the

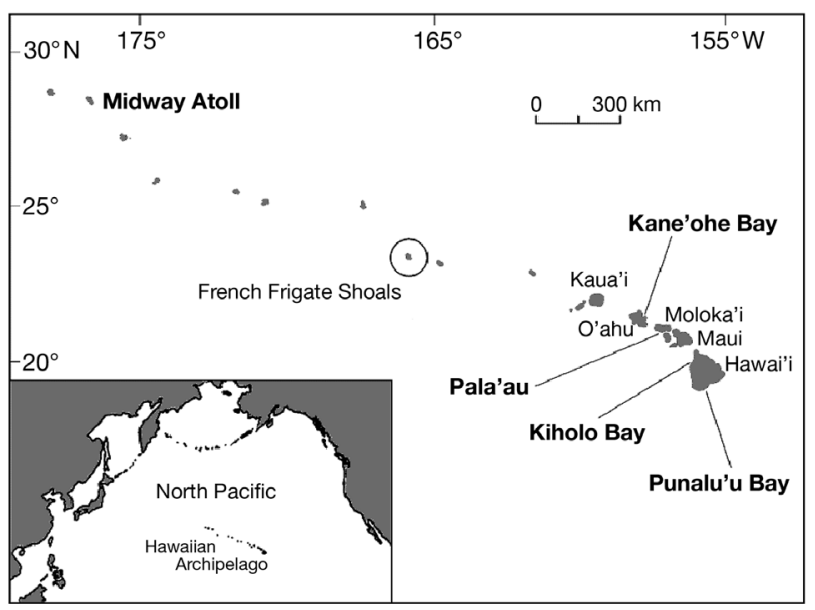

Fig. 1. Location of the 5 Hawaiian green turtle foragingground study sites sampled (bold). The major rookery is at French Frigate Shoals located in the middle of the Hawaiian Archipelago 
Hawaiian Archipelago can be found in Balazs (1976, 1980, 1982) and Balazs \& Chaloupka (2004b).

Turtles were captured using several methods, including tangle nets, bullpen or pound nets, scoop nets, and hand capture from small boats or by SCUBA or snorkel. Additionally, some turtles were captured while basking ashore at Kiholo, Punalu'u, and Midway. Further details of the capture and handling methods are given in Balazs (1982), Balazs et al. (1987), and Balazs \& Chaloupka (2004b). Blood samples were centrifuged and the packed red cells frozen. In addition, 115 skin samples were collected from an array of green turtles stranding at locations throughout the Hawaiian Islands (see Work et al. 2004).

Laboratory analysis. Specimens included packed red blood cells that were frozen or stored in lysis buffer or small skin biopsies preserved in a $20 \%$ dimethyl sulphoxide (DMSO) solution saturated with sodium chloride (Dutton 1996). DNA was isolated from these samples using either standard phenol/chloroform extraction techniques (Sambrook et al. 1989) or the Fast Prep DNA isolation kit (Bio101 $\left.{ }^{\circledR}\right)$. Amplification of mtDNA was performed by PCR (Innis et al. 1990) using the primers HDCM2 and LTCM2, designed to target $488 \mathrm{bp}$ at the $5^{\prime}$ end of the control region of the mitochondrial genome (Lahanas et al. 1994). Template DNAs were amplified in $50 \mu \mathrm{l}$ PCR reactions on a Perkin Elmer 480 thermocycler using the following profile: initial denaturation at $94^{\circ} \mathrm{C}$ for $2 \mathrm{~min}$, followed by 36 cycles of DNA denaturing at $94^{\circ} \mathrm{C}$ for $50 \mathrm{~s}$, primer annealing at $52^{\circ} \mathrm{C}$ for $2 \mathrm{~min}$, and primer extension at $72^{\circ} \mathrm{C}$ for $1 \mathrm{~min} 30 \mathrm{~s}$, followed by a final primer extension for $5 \mathrm{~min}$ at $72^{\circ} \mathrm{C}$. The sizes of the amplified products were determined using electrophoresis in a $2 \%$ agarose gel stained with ethidium bromide. PCR products were then purified using the Qiaquick PCR Purification Kit (Qiagen $\left.{ }^{\circledR} 1995\right)$ and stored at $4^{\circ} \mathrm{C}$. Direct cycle- sequencing reactions of the light strand were performed on $2 \mu$ l of purified PCR product combined with $2 \mu$ l of ABI Prism ${ }^{\circledR}$ dRhodamine Terminator Cycle Sequencing Kit, $3 \mu$ l of primer LTCM2 and $5 \mu$ of purified water. The labeled extension products were purified via ethanol precipitation and analyzed with an Applied Biosystems model 377 automated DNA Sequencer. The sequences were analyzed for uncalled and miscalled bases using either Gene Codes Sequencher 3.1.1 or ABI SeqED v. 1.0.2. Sequences were aligned against reference data from the $384 \mathrm{bp}$ segment of the mtDNA control region corresponding to the region reported by Norman et al. (1994). Haplotype nomenclature follows that reported by the Southwest Fisheries Science Center (http://swfsc.noaa.gov/ prd-turtles.aspx) and were based on the same 384bp fragment used by Norman et al. (1994), and Dethmers et al. (2006) to assign haplotypes.
Statistical analysis. The mtDNA haplotypes that were identified at all of the Hawaiian FGs were compared with published and unpublished data for all rookeries sampled in the Pacific and Indian Ocean to identify potential source stocks to use in the mixed stock analysis (MSA) (Norman et al. 1994, ChassinNoria et al. 2004, Dethmers et al. 2006, Bourjea et al. 2007, P. H. Dutton et al. unpubl. data). Haplotype frequencies were compared among the 5 FGs using a $\chi^{2}$ test (Roff \& Bentzen 1989), as implemented in the program CHIRXC (Zaykin \& Pudovkin 1993). The FG haplotype frequencies were then compared with those reported for 4 Pacific rookeries that contain haplotypes we found present at the Hawaiian FG. We performed MSA using Markov chain Monte Carlo (MCMC) methods as implemented in the program BAYES (Pella \& Masuda 2001). Estimates of contributions by different nesting populations to the Hawaii FG were based on Bayesian analysis using MCMC estimation from 6320 re-samplings of 4 stock mixtures composed of green turtles from 4 potential source stocks (Chassin-Noria et al. 2004, P. H. Dutton et al. unpubl. data). Western Pacific and Indian Ocean nesting stocks were not included as potential sources in this analysis, since haplotypes that characterize these stocks were not found at the Hawaiian FG.

\section{RESULTS}

Six haplotypes were identified from sequences for the 788 green turtles sampled from all of the Hawaiian Archipelago FGs and strandings (Table 1). Samples were available which allowed between-year comparisons of haplotype frequencies for turtles sampled at one of the FGs (Pala'au, Molokai) and we found no significant differences ( $p>0.5, \mathrm{df}=1$ ) (see LeRoux et al. 2003). This indicates temporal stability among haplotype composition and that annual sampling was representative for this site within the time frame of our study. There were no significant differences in haplotype frequencies among the 5 Hawaiian Archipelago FGs $\left(\chi^{2}=\right.$ 12.19, df $=16, \mathrm{p}>0.5$ ), so the data from all FG were combined for subsequent analysis. There was also no significant difference among haplotype frequencies of the strandings, compared with the FGs. Haplotype CMP1 was the most common, found in $64 \%$ of the FG samples, with CMP3 (15\%) and CMP2 (10\%) making up most of the rest (Table 1). The FFS rookery is the only breeding site where CMP2 has been detected, and neither CMP 1 nor CMP3 have been detected at any of the western Pacific rookeries (Dethmers et al. 2006, D. Broderick pers. comm., P. H. Dutton unpubl. data), and only at one eastern Pacific rookery (Revillagigedos, Table 1). Three additional haplotypes (not detected in 
Table 1. Green turtle haplotype composition for the Hawaiian feeding ground populations and strandings compared with nesting population data (from Chassin-Noria et al. 2004; P. H. Dutton et al. unpubl. data) used in mixed stock analysis. MICH = Michoacan rookery; REV = Revillagigedos; FFS = French Frigate Shoals

\begin{tabular}{|c|c|c|c|c|c|c|c|c|c|c|c|}
\hline \multirow{2}{*}{$\begin{array}{l}\text { Haplo- } \\
\text { type }\end{array}$} & \multirow{2}{*}{$\begin{array}{l}\text { Mexico } \\
\mathrm{MICH}\end{array}$} & \multicolumn{3}{|c|}{ Nesting population } & \multicolumn{6}{|c|}{ Feeding ground population } & \multirow{2}{*}{$\begin{array}{c}\text { Hawaii } \\
\text { strandings }\end{array}$} \\
\hline & & $\begin{array}{c}\text { Mexico } \\
\text { REV }\end{array}$ & Galapagos & $\begin{array}{c}\text { Hawaii } \\
\text { FFS }\end{array}$ & Pala'au & Kiholo & $\begin{array}{c}\text { Kane'ohe } \\
\text { Bay }\end{array}$ & Midway & Punalu'u & Total & \\
\hline CMP1 & & 1 & & 156 & 227 & 57 & 91 & 45 & 57 & 477 & 76 \\
\hline CMP2 & & & & 34 & 42 & 3 & 14 & 14 & 9 & 82 & 16 \\
\hline CMP3 & & 11 & & 39 & 54 & 10 & 22 & 10 & 16 & 112 & 22 \\
\hline CMP4 & 82 & 23 & 95 & & & & & & & & 1 \\
\hline CMP5 & 34 & & & & & & & & & & \\
\hline CMP6 & & 50 & & & 1 & & & & & 1 & \\
\hline CMP7 & 2 & & & & & & & & & & \\
\hline CMP8 & 2 & & & & & & & & & & \\
\hline CMP9 & & 2 & & & & & & & & & \\
\hline CMP10 & & 1 & & & & & & & & & \\
\hline CMP11 & & 1 & & & & & & & & & \\
\hline CMP12 & 3 & & & & & & & & & & \\
\hline CMP13 & & 1 & & & & & & & & & \\
\hline CMP15 & & & 3 & & & & & & & & \\
\hline CMP20 & & & & & 1 & & & & & 1 & \\
\hline Total & 123 & 90 & 98 & 229 & 325 & 70 & 127 & 69 & 82 & 673 & 115 \\
\hline
\end{tabular}

the FFS rookery) were found in 3 of the 788 FG and stranded turtles (Table 1). Two of these came from the Pala'au FG, and the third case was a turtle missing both front flippers that stranded alive on the northeast coast of Oahu. Haplotype CMP20 is primarily found in the western Pacific (Dethmers et al. 2006), while haplotypes CMP4 and CMP6 occur in eastern Pacific rookeries, with CMP6 only identified at the Mexican rookery in the Revillagigedos Archipelago (Table 1; P. H. Dutton unpubl. data).

Haplotype frequencies were not significantly different from those at the FFS rookery (Table $1 ; \chi^{2}=3.1133$, df $=$ $5, \mathrm{p}>0.5)$. The MSA also confirmed that the Hawaii FG comprises animals of FFS nesting stock origin (Table 2).

Table 2. Mean estimated stock mixtures of green turtles from FG and strandings in the Hawaiian Archipelago using BAYES (Pella \& Masuda 2001). Analysis consisted of 10000 resamplings (20000 MCMC samples) of 4 stock mixtures composed of green turtles from 4 potential nesting stocks, including French Frigate Shoals (FFS, Hawaii), Islas Revillagigedos (Mexico-REV), Michoacan (Mexico-MICH) and Galapagos Islands (Ecuador). Median and 95\% confidence limits $(2.5$ and $97.5 \%$ quantiles) are shown

\begin{tabular}{|lccccc|}
\hline Nesting stock & Mean & SD & Median & \multicolumn{2}{c|}{$\begin{array}{c}\text { Lower } \\
\text { quantile }\end{array}$} \\
\hline FFS & & & & 0.993 & 1.000 \\
Mexico-REV & 0.001 & 0.002 & 0.001 & 0.000 & 0.006 \\
Mexico-MICH & 0.000 & 0.001 & 0.000 & 0.000 & 0.003 \\
Galapagos & 0.000 & 0.001 & 0.000 & 0.000 & 0.003 \\
\hline
\end{tabular}

\section{DISCUSSION}

Our results show that the foraging aggregations of green turtles in the Hawaiian Archipelago are from this north central Pacific nesting stock and can be considered a discreet MU separate from other Pacific stocks. Results also indicate that strandings are part of the same genetic stock, and that the individuals that strand are representative of the FG populations. The discovery of 3 individuals with haplotypes only found at rookeries other than FFS, suggests that the Hawaiian FGs are occasionally, albeit rarely, visited by turtles from rookeries outside of the Hawaiian Archipelago. It is possible that these 3 haplotypes are so rare that they were not detected at FFS, despite the relatively large sample size (Table 1; Dutton et al. in prep). However, 2 of these turtles (haplotypes CMP4 and CMP6) were visibly different from typical Hawaiian FG and FFS turtles; they both had a dark grey plastron, black carapace with distinct posterior indentations, typically associated with eastern Pacific green turtle stocks (see Karl \& Bowen 1999). The stranded turtle (CMP4, Table 1), while missing both flippers, was generally healthy, and believed to be a pelagic turtle that, having lost its ability to swim, had been carried by the northeast trade winds into the coastal waters of the exposed north shore of Oahu. We believe this animal would not normally have been found at the Hawaiian FGs. Juvenile green turtles of eastern Pacific stock origin have been caught by pelagic longlines on the high seas in the Central Pacific, suggesting occasional pelagic 
wandering by eastern Pacific green turtles (Dutton et al. 2000). The third non-endemic haplotype (CMP20), has been found at western Pacific rookeries in Micronesia and Melanesia (Dethmers et al. 2006). These rare wanderers might provide an avenue for historic colonization of Hawaii.

Our results show that the Hawaiian green turtle population is made up of a single primary rookery that is the source of the FG populations spanning a wide geographic range of more than $2400 \mathrm{~km}$ throughout the archipelago (Fig. 1). This finding contrasts with all the other FG studies of green turtles in the Atlantic (Bass et al. 1998, 2006, Lahanas et al. 1998, Bass \& Witzell 2000, Luke et al. 2004, Bowen et al. 2007) that have detected FG populations of mixed stock origins over comparable geographic scales. The general model that has emerged from these studies of long-range oceanic transport of juveniles from multiple nesting stocks facilitating settlement into overlapping FGs clearly is not applicable to the central North Pacific.

\section{Dispersal patterns}

Our results suggest that, after hatching at FFS, pelagic juveniles spend their oceanic years in the north central Pacific region and settle into FGs around the Hawaiian Archipelago (see Balazs 1976). The extent to which Hawaiian green turtles disperse to foraging areas in either the eastern or western Pacific is unknown, and further research that includes sampling of mutiple FGs around the Pacific should address this point. Satellite telemetry has shown that nesters from FFS also forage in the waters around Johnston Atoll, immediately south of the Hawaiian Archipelago (Balazs 1985b, 1994); however, it appears that the range of Hawaiian green turtles does not extend beyond the central Pacific region. Preliminary genetic results from foraging areas in Southern California, Baja California, and the eastern tropical Pacific do not indicate the presence of Hawaiian green turtles (P. H. Dutton, unpubl. data). Similarly, the strandings from the coast of Alaska (Hodge \& Wing 2000), Oregon and northern California that have been analyzed to date have all been of eastern Pacific stock origin (Dutton 2003, unpubl. data). Likewise, studies to date have not found green turtles of Hawaiian origin in the western Pacific (Norman et al. 1994, Dethmers \& Broderick 2003, P. H. Dutton unpubl. data) or at Melanesian FGs (P. H. Dutton unpubl. data, see Boyle 1998). This indicates that dispersal from the Hawaiian population may be constrained by geographic isolation and oceanographic conditions that prevent successful migration to FGs beyond the central Pacific. Further work is needed to examine stock composition of pelagic juveniles to test the hypothesis that these early stage juveniles are also from the Hawaiian genetic stock. In addition, oceanographic studies that model current patterns would enable better understanding of the transport processes that may influence dispersal and delineate the boundaries of this population. Surface drift trajectories compiled from average current measurements suggest that hatchlings entering the ocean at FFS during the hatching season would be transported in a northwesterly direction (Balazs 1976). However, the longer range processes are poorly studied and little is known about the pelagic ecology of sea turtles in general.

Our genetic findings are consistent with ecological studies of local dispersal of green turtles in the Hawaiian Archipelago. Long-term CMR studies have indicated that green turtles take up residence at local FGs as juveniles and that there is limited movement among various FGs (Balazs 1980, 1983, see Balazs \& Chaloupka 2004b). Adult green turtles are also resident in these FGs and migrate every few years to breed and nest at FFS (Balazs 1983, 1994).

Our study builds on previous demographic and ecological studies by integrating genetic data to produce a simple model describing the structure of the population of green turtles in the Hawaiian Archipelago. The population model we propose (Fig. 2) for the Hawaiian Archipelago contrasts with more complex ones typical of green turtles, and sea turtles in general (Chaloupka 2004), in which a genetically distinct stock comprises multiple rookeries and FGs that overlap with several other genetic stocks (Lahanas et al. 1998, Limpus et al. 2003, Chaloupka 2004, Bass et al. 2006). Chaloupka \& Balazs (2007) have characterized the Hawaiian green turtle FG populations ecologically as a metapopulation of geographically dispersed and disjunct FGs, with dispersal among nearby populations more likely than dispersal among distant populations. Our genetic results show that these FGs are part of a single panmictic

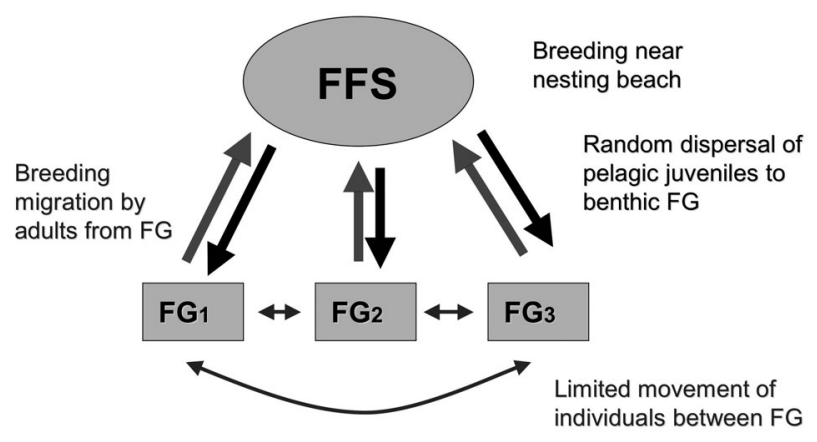

Fig. 2. Simplified schematic model of dispersal and gene flow among the Hawaiian green turtle population (FFS = French Frigate Shoals breeding sites). Feeding grounds (FG1, FG2, FG3, etc.) represent generalised feeding grounds that occur within the Hawaiian Archipelago 
breeding population (Fig. 2). In terms of risk management, specific threats (such as disease, anthropogenic impacts) acting differentially at different FGs may lead to local depletions of foraging aggregations. However, these aggregations have the potential of rapid recovery as long as hatchling production in the nesting population is maintained.

This contrasts sharply with other more socially complex migratory marine vertebrates, such as humpback whales, who recruit to different FGs by learning the migratory routes as calves from their mothers. In the North Atlantic, humpback whales consist of demographically isolated FG populations which are genetically differentiated from each other in terms of matrilinear mtDNA lineages. Adults, however, migrate from these FGs to interbreed at a single wintering ground in the West Indies, thus maintaining panmixia at the nuclear level, since nuclear DNA is inherited from both parents (Larsen et al. 1996, Palsböll et al. 1997, Smith et al. 1999). If a FG population of humpback whales in Norway was decimated by a catastrophic event, it might take decades to re-establish, since the migratory routes are learned from the mothers. However, in the case of Hawaiian green turtles, a depleted FG population would re-establish itself relatively rapidly, since juveniles would recruit there randomly. This process might help maintain a buffer for the population as a whole against localized catastrophic impacts on a FG, but not if the threat was persistent (e.g. disease, habitat degradation, or over-harvest), since the risky FG would remain as a 'drain' on the population. Furthermore, unlike other sea turtle FGs containing animals from multiple nesting stocks, the Hawaiian population, supported by a single primary rookery, would be more vulnerable to impacts at the breeding sites at FFS.

One such impact of recent concern is the potential effect of sea level rise on the northern islets of FFS (Baker et al. 2006). For example, Whale-Skate was once a primary nesting site at FFS (Balazs 1976) but by 2004 the island, along with several other prominent nesting islands, had been reduced by erosion to a fraction of its size recorded in 1963 (Amerson 1971, Antonelis et al. 2006). The reasons for this loss of habitat are not clearly understood, but turtle nesting has shifted to the other islets in the FFS, such as Tern Island, where there has been periodic artificial shoreline restoration.

\section{Conservation implications}

The green turtle is listed as 'Threatened' under the US ESA throughout its Pacific range, except for the population nesting on the Pacific coast of Mexico that is listed under the ESA as 'Endangered' (NMFS and US-
FWS 1998). ESA objectives focus on recognizing the biological and ecological importance of discrete populations (DPS) and taking action when necessary to preserve them (USFWS-NOAA 1996). Inability to clearly define stock boundaries, and an incomplete understanding of population structure and dispersal patterns have made it difficult to recognize appropriate demographic units for conservation purposes. This has led to a bias toward defining sea turtle Evolutionary Significant Units (ESUs) and MUs (Moritz 1994) based solely on their rookery stock structure. Previous studies involving the FFS rookery have focused on phylogeographic-level divergence of mtDNA which reveals ancient divergence among ocean basins and identifies FFS as an ESU and demographically discreet MU (Bowen et al. 1992, Moritz 1994, Bowen \& Avise 1995, P. H. Dutton unpubl. data). Our genetic findings, combined with information on phylogeography, ecology, habitat and population trends, support the conclusion that the foraging and nesting populations of green turtles throughout the Hawaiian Archipelago essentially comprise a panmictic, demographically discrete and biologically and ecologically significant population of green turtles. These findings should influence future decisions about DPS designations for this species.

Acknowledgements. Many thanks to Erin LaCasella, Danielle Beattie, Elyse Bixby, Lauren Hansen, Vicki Pease and Amy Frey for their assistance with laboratory analysis. For extensive long-term support of and contributions to the Hawaiian sea turtle genetics and biological research program we thank the following individuals, agencies and organizations: Bridget McBride, Donna Brown, Shandell Brunson, Sallie Beavers, John Coney, Skippy Hau, Leon Hallacher, Don Heacock, Cody Hooven, Joy Oliveira, Erin Siebert, Sherwood Maynard, Bill Puleloa, Marc Rice, Darren Marshall, Thierry Work, Bob Morris, and Jason Turner, State of Hawai'i Division of Aquatic Resources and Division of Conservation and Resources Enforcement, Marine Option Program at the University of Hawai'i at Manoa, Hilo and Maui Community College, the Hawai'i Preparatory Academy, and the NOAA Hawaiian Islands Humpback Whale National Marine Sanctuary. Data and samples presented in this paper were collected within the Hawaiian Islands National Wildlife Refuge overseen by the USFWS, Department of the Interior, according to permit guidelines. Samples and data from Galapagos were collected within the Galapagos National Park with cooperation from the Charles Darwin Research Foundation, and from Revillagigedos with assistance from Arturo Ceron, and permission from SEMARNAT, according to collection and CITES permit conditions. We thank Milani Chaloupka, Brian Bowen, Greg O'Corrie-Crowe, Phillip Morin, George Antonelis, Jeffrey Seminoff, Stacy Kubis, Denise Parker, and Melissa Snover and anonymous reviewers for helpful input on the manuscript.

\section{LITERATURE CITED}

Amerson AB (1971) The natural history of French Frigate Shoals, Northwestern Hawaiian Islands. Atoll Res Bull 150:1-383 
Antonelis GA, Baker JD, Johanos TC, Braun RC, Harting AL (2006) Hawaiian monk seal (Monachus schauinslandi): status and conservation issues. Atoll Res Bull 543: 75-101

Baker JD, Littnan CL, Johnston DW (2006) Potential effects of sea-level rise on the terrestrial habitats of endangered and endemic megafauna in the Northwestern Hawaiian Islands. Endang Species Res 2:21-30

Balazs GH (1976) Green turtle migrations in the Hawaiian Archipelago. Biol Conserv 9:125-140

Balazs GH (1980) Synopsis of biological data on the green turtle in the Hawaiian Islands. NOAA Tech Memo NMFSSWFSC 7:1-141

Balazs GH (1982) Growth rates of immature green turtles in the Hawaiian Archipelago. In: Bjorndal KA (ed) Biology and conservation of sea turtles. Smithsonian Institution Press, Washington DC, p 117-125

Balazs GH (1983) Recovery records of adult green turtles observed or originally tagged at French Frigate Shoals, Northwestern Hawaiian Islands. NOAA Tech Memo NMFS-SWFC 36:1-42

Balazs GH (1985a) History of sea turtles at Polihua beach on northern Lanai. Elapio 46:1-3

Balazs GH (1985b) Status and ecology of marine turtles at Johnston Atoll. Atoll Res Bull 285:1-46

Balazs GH (1994) Homeward bound: satellite tracking of Hawaiian green turtles from nesting beaches to foraging pastures. In: Schroeder BA,Witherington B (compilers) Proc 13th Annu Symp on Sea Turtle Biology and Conservation. NOAA Tech Memo NMFS-SEFSC-341, National Technical Information Service, Springfield, VA, p 205-208

Balazs GH (2000) Assessment of Hawaiian green turtles utilising coastal foraging pastures at Pala'au, Molokai. In: Bjorndal KA, Bolten AB (eds) Proceedings of a Workshop on Assessing Abundance and Trends for In-Water Sea Turtle Populations. NOAA Tech Memo NMFS-SEFSC445. National Technical Information Service, Springfield, VA, p 42-45

Balazs GH, Chaloupka M (2004a) Thirty-year recovery trend in the once depleted Hawaiian green sea turtle stock. Biol Conserv 117:491-498

Balazs G, Chaloupka M (2004b) Spatial and temporal variability in somatic growth of green sea turtles resident within the Hawaiian Archipelago. Mar Biol 145: 1043-1059

Balazs GH, Chaloupka M (2006) Recovery trend over 32 years at the Hawaiian green turtle rookery of french frigate shoals. Atoll Res Bull 543:147-158

Balazs GH, Forsyth RG, Kam AKH (1987) Preliminary assessment of habitat utilization by Hawaiian green turtles in their resident foraging pastures. NOAA Tech Memo NOAA-TM-NMFS-SWFC-71

Balazs GH, Dudley WC, Hallacher LE, Coney JP, Koga SK (1994) Ecology and cultural significance of sea turtles at Punalu'u, Hawaii. In: Bjorndal KA, Bolten AB, Johnson DA, Eliazar PJ (eds) Proceedings of the Fourteenth Annual Symp on Sea Turtle Biology and Conservation. NOAA Tech Memo NMFS-SEFSC-351. National Technical Information Service, Springfield, VA, p 10-13

Balazs GH, Rice M, Hoffman N, Murakawa SKK, Parker DM, Shallenberger RJ (2005) Green turtle foraging and resting habitats at Midway Atoll: significant findings over 25 years, 1975-2000. In: Coyne M, Clark RD (compilers) Proceedings of the Twenty First Annual Symposium on Sea Turtle Biology and Conservation. NOAA Tech Memo NMFS-SEFSC-528, National Technical Information Service, Springfield, VA, p 102-104
Bass AL, Witzell WN (2000) Demographic composition of immature green turtles (Chelonia mydas) from the east central Florida coast: evidence from mtDNA markers. Herpetologica 3:357-367

Bass AL, Lagueux CJ, Bowen BW (1998) Origin of green turtles, Chelonia mydas, at 'sleeping rocks' off the northeast coast of Nicaragua. Copeia 4:1064-1069

Bass AL, Epperly SP, Braun-Mcneill J (2006) Green turtle (Chelonia mydas) foraging and nesting aggregations in the Caribbean and Atlantic: impact of currents and behavior on dispersal. J Hered 97:346-354

- Bourjea J, Lapègue S, Gagnevin L, Broderick D and others (2007) Phylogeography of the green turtle, Chelonia mydas, in the Southwest Indian Ocean. Mol Ecol 16: $175-186$

Bowen BW (1997) Complex population structure and the conservation genetics of migratory marine mammals: lessons from sea turtles. In: Dizon AE, Chivers SJ, Perrin WF (eds) Molecular genetics of marine mammals. J Mar Mammal Spec Publ 3, p 77-84

Bowen BW, Avise JC (1995) Conservation genetics of marine turtles. In: Avise JC, Hamrick JL (eds) Conservation genetics: case studies from nature. Chapman \& Hall, New York, p 190-237

Bowen BW, Karl SA (1997) Population genetics, phylogeography and molecular evolution. In: Lutz PL, Musick JA (eds) The biology of sea turtles. CRC Press, New York, p 29-50

Bowen BW, Meylan AB, Perran Ross J, Limpus CJ, Balazs GH, Avise JC (1992) Global population structure and natural history of the green turtle (Chelonia mydas) in terms of matriarchal phylogeny. Evolution 46:865-881

> Bowen BW, Bass AL, Soares L, Toonen RJ (2005) Conservation implications of complex population structure: lessons from the loggerhead turtle (Caretta caretta). Mol Ecol 14:2389-2402

> Bowen BW, Grant WS, Hillis-Starr Z, Shaver D, Bjorndal KA, Bolten AB, Bass AL (2007) Mixed stock analysis reveals the migrations of juvenile hawksbill turtles (Eretmochelys imbricata) in the Caribbean Sea. Mol Ecol 16:49-60

Boyle M (1998) Sea turtles of Fiji: Aspects of population biology and conservation implications of harvesting. MS thesis, University of Otago, Dunedin

Chaloupka M (2004) Exploring the metapopulation dynamics of the southern Great Barrier Reef green sea turtle stock and the possible consequences of sex-biased local harvesting. In: Akcakaya $\mathrm{H}$, Burgman $\mathrm{M}$, Kindvall $\mathrm{O}$, Wood C, Sjogren-Gulve P, Hattfield J, McCarthy M (eds) Species conservation and management: case studies. Oxford University Press, New York, p 340-354

Chaloupka M, Balazs GH (2007) Using Bayesian state-space modelling to assess the recovery and harvest potential of the Hawaiian green sea turtle stock. Ecol Model 205: 93-109

Chaloupka M, Limpus C, Miller J (2004) Green turtle somatic growth dynamics in a spatially disjunct Great Barrier Reef metapopulation. Coral Reefs 23:325-335

Chaloupka M, Bjorndal KA, Balazs G, Bolten AB and others (2008) Encouraging outlook for recovery of a once-severely-exploited marine megaherbivore and restoration of its ecological function. J Global Ecol Biogeogr 17:297-304

Chassin-Noria O, Abreu-Grobois A, Dutton PH, Oyama K (2004) Conservation genetics of the east Pacific green turtle (Chelonia mydas) in Michoacan, Mexico. Genetica 1891:1-12

Dethmers K, Broderick D (2003) Green turtle fisheries in Australasia: assessing the extent of their impact using mtDNA markers. In: Salmon M, Wyneken J (compilers) Proceed- 
ings of the Twenty Second Annual Workshop on Sea Turtle Biology and Conservation. NOAA Tech Memo NMFS-SEFC-503, National Technical Information Service, Springfield, VA, p 41-43

> Dethmers KEM, Broderick D, Moritz C, Fitzsimmons NN and others (2006) The genetic structure of Australasian green turtles (Chelonia mydas): exploring the geographical scale of genetic exchange. Mol Ecol 15:3931-3946

Dutton PH (1996) Methods for collection and preservation of samples for sea turtle genetic studies. In: Bowen BW, Witzell WN (eds) Proceedings of the International Symposium on Sea Turtle Conservation Genetics. NOAA Tech Memo NMFS-SEFSC-396, National Technical Information Service, Springfield, VA, p 17-24

Dutton PH (2003) Molecular ecology of the eastern Pacific green turtle. In: Seminoff J (compiler) Proceedings of the Twenty Second Annual Symposium on Sea Turtle Biology and Conservation. NOAA Tech Memo NMFS-SEFSC-503, National Technical Information Service, Springfield, VA, p 69

Dutton PH, Bowen BW, Owens DW, Barragan A, Davis SK (1999) Global phylogeography of the leatherback turtle (Dermochelys coriacea). J Zool (Lond) 248:397-409

Dutton PH, Bixby E, LeRoux R, Balazs GH (2000) Genetic stock origin of sea turtles caught in the Hawaii-based longline fishery. In: Kalb HJ, Wibbels T (compilers) Proceedings of the Nineteenth Annual Symposium on Sea Turtle Biology and Conservation. NOAA Tech Memo NMFS-SEFSC-443, National Technical Information Service, Springfield, VA, p 120-121

Encalada SE, Lahanas PN, Bjorndal KA, Miyamoto MM, Bowen BW (1996) Phylogeography and population structure of the Atlantic and Mediterranean green turtle Chelonia mydas: a mitochondrial DNA control region sequence assessment. Mol Ecol 5:473-483

FitzSimmons NN, Limpus CJ, Norman JA, Goldizen AR, Miller JD, Moritz C (1997) Philopatry of male marine turtles inferred from mitochondrial DNA markers. Proc Natl Acad Sci USA 94:8912-8917

Fraser DJ, Bernatchez L (2001) Adaptive evolutionary conservation: towards a unified concept for defining conservation units. Mol Ecol 10:2741-2752

Hays GC (2004) Good news for sea turtles. Trends Ecol Evol 19:349-351

Hodge RP, Wing BL (2000) Occurrence of marine turtles in Alaska waters: 1960-1998. Herpetol Rev 31:148-151

Innis MA, Gelfand DH, Sninsky JJ, White TJ (1990) PCR Protocols: a guide to methods and applications. Academic Press, San Diego, CA

Karl SA, Bowen BW (1999) Evolutionary significant units versus geopolitical taxonomy: molecular systematics of an endangered sea turtle (genus Chelonia). Conserv Biol 13:990-999

- Lahanas PN, Miyamoto MM, Bjorndal KA, Bolten AB (1994) Molecular evolution and population genetics of greater Caribbean green turtles (Chelonia mydas) as inferred from mitochondrial DNA control region sequences. Genetica 94:57-67

Lahanas PN, Bjorndal KA, Bolten AB, Encalada SE, Miyamoto MM, Valverde RA, Bowen BW (1998) Genetic composition of a green turtle (Chelonia mydas) feeding ground population: evidence for multiple origins. Mar Biol 130:345-352

Larsen AH, Sigurjonsson J, Oien N, Vikingsson G, Palsböll PJ (1996) Population genetic analysis of nuclear and mito- chondrial loci in skin biopsies collected from central and northeastern North Atlantic humpback whales (Megaptera novaeangliae): Population identity and migratory destinations. Proc R Soc Lond B Biol Sci 263: 1611-1618

LeRoux RA, Balazs GH, Dutton PH (2003) Genetic stock composition of foraging green turtles off the southern coast of Molokai, Hawaii, USA. In: Seminoff J (compiler) Proceedings of the Twenty Second Annual Symposium on Sea Turtle Biology and Conservation. NOAA Tech Memo NMFS-SEFSC-503. National Technical Information Service, Springfield, VA, p 251-252

Limpus CJ, Miller JD, Parmenter CJ, Limpus DJ (2003) The green turtle, Chelonia mydas, population of Raine Island and the northern Great Barrier Reef:1843-2001. Mem Queensl Mus 49:349-440

Luke K, Horrocks JA, LeRoux R, Dutton PH (2004) Origins of green turtle (Chelonia mydas) feeding aggregations around Barbados, West Indies. Mar Biol 144:799-805

> Moritz C (1994) Applications of mitochondrial DNA analysis in conservation: a critical review. Mol Ecol 3:401-411

NMFS and USFWS (National Marine Fisheries Service and US Fish and Wildlife Service) (1998) Recovery plan for US Pacific populations of the green turtle (Chelonia mydas). National Marine Fisheries Service, Silver Spring, MD

Norman JA, Moritz C, Limpus CJ (1994) Mitochondrial DNA control region polymorphisms: genetic markers for ecological studies of marine turtles. Mol Ecol 3:363-373

Palsböll PJ, Allen J, Berube M, Clapham PJ and others (1997) Genetic tagging of humpback whales. Nature 388: $767-769$

Pella J, Masuda M (2001) Bayesian methods for analysis of stock mixtures from genetic characters. Fish Bull (Wash DC) 99:151-167

Reece JS, Castone TA, Parkinson CL (2005) Historical perspectives on population genetics and conservation of three marine turtle species. Conserv Gen 6:235-251

$>$ Roff DA, Bentzen P (1989) The statistical analysis of mitochondrial DNA polymorphisms and the problem of small samples. Mol Biol Evol 6:539-545

Sambrook J, Fritsch EF, Maniatis T (1989) Molecular cloning: A laboratory manual, 2nd edn. Cold Spring Harbor Laboratory Press, New York

Smith TD, Allen J, Clapham PJ, Hammond PS and others (1999) An ocean-wide mark-recapture study of the North Atlantic humpback whale (Megaptera novaeangliae). Mar Mamm Sci 15:1-32

USFWS-NOAA (United States Fish and Wildlife ServiceUnited States National Oceanic and Atmospheric Administration) (1996) Policy regarding the recognition of distinct vertebrate population segments under the Endangered Species Act. US Fed Regist 61:4722-4725

Work TM, Balazs GH, Rameyer RA, Morris RA (2004) Retrospective pathology survey of green turtles Chelonia mydas with fibropapillomatosis in the Hawaiian Islands, 1993-2003. Dis Aquat Org 62:163-176

Zaykin DV, Pudovkin AI (1993) Two programs to estimate significance of $\mathrm{X} 2$ values using pseudo-probability tests. J Hered 84:152

Zug GR, Balazs GH, Wetherall JA, Parker DM, Murakawa SKK (2002) Age and growth in Hawaiian green sea turtles (Chelonia mydas): an analysis based on skeletochronology. Fish Bull (Wash DC) 100:117-127

Submitted: October 2, 2007; Accepted: May 1, 2008

Proofs received from author(s): August 2, 2008
Editorial responsibility: Mike Bruford,

Cardiff, UK 